\title{
On the Aesthetic Value of A Psalm of Life
}

\author{
YuXia Fan ${ }^{1, a, *}$ \\ Kaifeng University,Kaifeng,Henan province,475004 China
}

\section{Abstract:}

A Psalm of Life by American romantic poet Henry Wadsworth Longfellow is a lyric created for deep reflection. It reveals the optimistic theme - time is fleeting, act in the living present. The poem appeals to the readers' eyes, ears, minds and emotions and shows the poet's richly endowed talents for both aesthetics and language manipulation as well. This article give the brief analysis of the poem, represent the rhetorical devices in the poem and gives the aesthetic value of he rhythm and rhyme.

Key Words: Rhetorical devices,Aesthetic value , Rhythm and rhyme:

\section{Introduction:}

Longfellow was born in Portland, Maine, on February 27,1807 ,into a family of established tradition and moderate means. He published his first poem at thirteen when he was a sophomore in Bowdoin College. From them on, he dreamed of "future eminence in literature". With his perseverance, he became one of the most serious writers of his age, and also a poet, enormously popular. He combined considerable learning with an enlightened understanding of the people, and he expressed the lives and ideals of humbler Americans in poems that they could not forget. Amid the rising democracy of his day, Longfellow became the national bard. His more popular poems strongly reflected the optimistic sentiment and the love of a good lesson that characterized the humanitarian spirit of the people. Among those poems is A Psalm of Life.

\section{The poem itself:}

A Psalm of Life

WHAT THE HEART OF THE YOUNG MAN SAID TO THE PSALMIST

Tell me not, in mournful numbers,

Life is but an empty dream! -

For the soul is dead that slumbers,
And things are not what they seem.

Life is real! Life is earnest!

And the grave is not its goal;

Dust thou art, to dust returnest,

Was not spoken of the soul.

Not enjoyment, and not sorrow,

Is our destined end or way;

But to act, that each tomorrow

Find us farther than today.

Art is long, and Time is fleeting,

And our hearts, though stout and brave,

Still, like muffled drums, are beating

Funeral marches to the grave.

In the world's broad field of battle,

In the bivouac of Life,

Be not like dumb, driven cattle!

Be a hero in the strife!

Trust no Future, howe'er pleasant!

Let the dead Past bury its dead!

Act, ——act in the living Present!

Heart within, and God o'erhead!

Lives of great men all remind us

We can make our lives sublime,

And, departing, leave behind us

Footprints on the sands of time,

Footprints, that perhaps another,

Sailing o'er life's solemn main,

A forlorn and shipwrecked brother,

Seeing, shall take heart again. 
Let us, then, be up and doing,

With a heart for any fate;

Still achieving, still pursuing,

Learn to labor and to wait.

\section{Analysis of the poem:}

The title of this poem is surely a friend of the reader. It tells us what attitude we should take toward the reading of the poem. After reading through the poem, we gather that it is not used ironically- that is, to set up an anticipation not realized. The poem is a psalm of life, not a psalm of death. If, from the title alone, we get the idea that the poem's motion will be positive, energetic, and lyrical, we will not be too far from the truth. Further, that it is entitled a "psalm" is a help to the reader. A psalm is ordinarily thought of as a sacred song or poem sung in praise of God. We are warned in advance, then, to take this statement not only seriously but religiously. The subtitle identifies the speaker of the poem as the "heart" of a young man, or, better perhaps, a young man speaking from the fullness of his heart. The character imputed to the speaker would be quite different if the subtitle read "the mind of the young man". For dramatic purposes the speaker is addressing "the psalmist". That title is ordinarily given to David whose Biblical hymns are collected in the Book of Psalms. In the dramatic situation of the poem, the young man who might have been reading the Book of Psalms has apparently been struck by the tone of sorrow inherent in some of them. "My life is as nothing before Thee: every man is nothing but a breath. Man passes like a mere shadow, his confusion is all in vain; he stores up and knows not who shall take possession of those things." (Many of the psalms are, of course, joyous, but those do not seem to be the ones which have stimulated the young man's reaction.)

The very first lines of the poem tell the reader that this poem is going to be a kind of rebuttal; an argumentative situation is the genesis of the poem. The use of direct address helps us to understand how the poem will proceed in its vigorous dissent.

Tell me not, in mournful numbers,
Life is but an empty dream!-

His retort is quick and to the point, not delayed for a consideration of the impact of his opponent's point of view.

Life is real! Life is earnest!

And the grave is not its goal;

After the first three stanzas, the argument of the opposition is no longer even summarized. Most of the poem presents a series of assertions which deny the notion that life is an empty dream. The speaker warms to his subject, and, at the very least, by stanza 4 he is speaking to anyone who will listen-to the whole world. The hortatory injunctions to the reader, as in line 5 and the final stanza, are rhetorical devices demanding our belief, and demanding further that we act on the basis of that belief.

If we trace the young man's argument, we find that it is made up of a series of bold and dauntless assertions, presented without evidence or dramatized experience to support the assertions. The assertions themselves, as rhetorical devices, attempt to create a tone of :"Believe me! I'm telling the truth! No doubt about it!"

Tell me not

Life is real! Life is earnest!

Art is long, and time is fleeting

Trust no Future, howe'er pleasant

Act, - - act in the living Present

We can make our lives sublime

Let us, then, be up and doing

A poem built upon a significant number of assertions will always contain a good deal of rhetoric. A poem like this one may possibly remind the reader of an oration. In the nineteenth century this kind of technique was expected of the speaker and prose writer. The spaciousness of nineteenth century rhetoric has been well explained by Richard Weaver in terms of the expectations of the audience and the speaker's awareness of these expectations. That life was real and earnest, for instance, did not need to be proved to such an audience, only asserted pleasantly, charmingly, movingly. Perhaps there is too much of that spaciousness in Longfellow's poem, 
especially for the modern reader.

In any event, there is no question that friends of the reader abound in this poem. Paraphrasing it presents no problem, since the author gives us a conceptual statement of each of his steps in almost every stanza. Life is not an empty dream; it is real and earnest. Do not trust in a vague future or look to the past; act in the living present. We learn from great men that our lives can be an edifying example to those who come after us. So, trusting in God and the impulses of the heart, be up and doing and act in faith.

\section{Rhetorical devices in the poem:}

The decent sentiments are all too easily discovered in the poem. The rhetoric of the poem calls attention to itself in such a way that nothing else seems very important. The specific rhetorical devices are as follow:

1. Repetition in vocabulary and syntax: Stanza 2: Life is real! Life is earnest..... Dust thou art, to dust returnest // Stanza 3: Not enjoyment, and not sorrow // Stanza 4: Art is long and time is fleeting // Stanza 5: In the world's broad field of battle! In the bivouac of Life, Be not like dumb, driven cattle! Be a hero in the strife // Stanza 6: Act-act in the Living Present! Heart within, and God o'erhead! // Stanza 7: Lives of greatmen...make our lives sublime // Stanza 9: Still achieving, still pursuing, learn to labor and to wait.

The above repetitions in vocabulary and syntax help to heighten the lilting atmosphere of the poem, stress the didactic tone and echo in the whole context.

2. Simile: Our hearts ...like muffled drums...are beating. // Be not like dumb, driven cattle!

3. Metaphor: Life is but an empty dream! // In the world's broad field of battle,// In the bivouac of life.// leave behind us Footprints on the sands of time. // Footprints sailing o'er life's solemn main.

4. Personification: Funeral marches to the grave.// Let the dead Past bury its dead.// For the soul is dead that slumbers,// Footprints sailing o'er // Time is fleeting.

The rhetorical devices such as simile, metaphor, personification are used in the poem to achieve compelling effects which the readers cannot expect.
5. Antithesis: Not enjoyment, and not sorrow. // Art is long, and time is fleeting.// Heart within, and God o'erhead! //Still achieving, still pursuing. // Learn to labor and to wait.

6. Parallelism: Life is real, Life is earnest! // Dust thou art, to dust returnest. // And our hearts, though stout and brave. // Let us, then, be up and doing. /

Both antithesis and parallelism make balanced sentences and phrases which provoke the thoughts of the readers in the poem.

7. Exclamation: Life is but an empty dream! // Life is real! Life is earnest! // Be not like dumb, driven cattle! // Be a hero in the strife! // Trust no Future, howe'er pleasant! // Let the dead Past bury its dead! // Act—act in the living Present! // Heart within, and God o'erhead!

All the above exclamations strengthen the didactic tone of the poem which appeals to the readers to take correct attitudes towards Life.

\section{The aesthetic value of rhythm and rhyme:}

The author tries to make his message as pleasant as possible by the lilting character of the rhythm and the charm of the familiar-sounding ballad rhyme scheme. Now, let's see the aesthetic aspects of the poem in terms of rhythm and rhyme.

The rhythm of the whole poem is basically trochaic tetrameter. However, almost all the second and the fourth verses in each stanza end with a missing syllable which thus projects "dream, seem, goal, soul, way, today, brave, grave, life, strife, dead, o'erhead, sublime, time, main, again, fate, wait." In line 4 of stanza 4 , the first syllable "Fu-" is an extra one, "ne-" and "-ral" are all unstressed syllables. In line 4 of stanza 2 , the words "of the" are unstressed. In line 2 of stanza 6 , the words "its dead" are both stressed. It is these changes in syllable and stress that lead to the changes in rhythm which are combined with unity and regulation. Hence the rhythm avoids being tedious and can attract the readers' attention.

This poem is charming to the ear while the poem is being read. This is owed to the effects of rhythm. Meanwhile, the rhythm protrudes these words of important meaning, for examples, life, real, life, earnest, 
and, grave, not ,goal, dust, art, dust, returnest, was, spoken, soul in stanza 2.

In line 1 of stanza 2 , there is a caesura between "Life is real!" and "Life is earnest!" The caesura is marked with “ ", i.e. a double-bar. The caesura is placed within the line so that it causes the readers to have a medial pause which is also a part of rhythm. This pause makes the rhythm full of variation, full of natural beauty, full of modulation in tone.

The poetical enjambment is very common in English poems. For the sake of feet, or rhyme, or emphasis of certain element, or syntactical structure, a whole sentence is often divided into several lines, hence, the effects of rhythm come into being. In stanza 4, for example, the sentence "and our hearts, though stout and brave, are still beating like muffled drums" is divided into two lines as follow:

And our hearts, though stout and brave,

Still, like muffled drums, are beating.

In these two lines, "still, like muffled drums, are beating" is consistent in foot and rhyme with the first line "Art is long and time is fleeting", while "And our hearts, though stout and brave" matches in foot and rhyme the last verse "Funeral marches to the grave."

Rhyme is a kind of phonetic echo, or more precisely a phonemic matching in verse. From the Norman Conquest until the present century rhyme is a predominant feature of English metrical structure. It usually occurs at the end of a line, which is known as End Rhyme.

The rhyming scheme of A Psalm of Life is abab, cdcd, efef, ghgh, ijij, klkl, mnmn, opop, qrqr, Almost all the first and the third lines in each stanza are in the feminine rhyme. Feminine rhyme is a correspondence in sound between multi-syllabic words with unstressed endings and hence the impression of a lighter rhyme; as in Tell me not, in mournful numbers,

For the soul is dead that slumbers,

Life is real! Life is earnest !
Dust thou art, to dust returnest,

However, almost all the second and the fourth lines in each stanza are in the masculine rhyme which is a correspondence in sound between words ending in stressed syllables, typically a monosyllabic content word, and hence a 'strong' rhyme; as in

Life is but an empty dream!-

And things are not what they seem.

And the grave is not its goal;

Was not spoken of the soul.

Rhyme lends pleasure to our ear and aids memorization; Rhyme enhances poetic assertions by giving shape and unity to what is being conveyed.

\section{Conclusions:}

The poem A Psalm of Life was published in the Knickerbocker Magazine for September, 1838, and collected in Voices of the Night(1839). The"psalmist" of the subtitle, whose theme of "dust to dust" appears in line7, may have been David (the king of ancient Israel) or the writer of Ecclesiastes. The poem A Psalm of Life is among the best of Longfellow's didactic poetry. Longfellow's lapses into didacticism and sentimentality reflected the flabbier romanticism of his age, but he has remained in the tradition and memory of the American people. Admiration for Longfellow today rests on his gift for narrative and his daring experiments in narrative verse, on his balladry, his popularization of the national epic, his naturalization of foreign themes and poetic forms, his ability to bring his erudition within the range of general understanding, his versatile and sensitive craftsmanship, and perhaps beyond all else, on the large and endearing qualities of the man himself. 


\section{Reference}

[1] Botong Wang. Round the Realms of Gold[M].

Kaifeng: Henan University press, 1993.

[2] Joanna Thornborrow, Patterns in Language: Stylistics

for Students of Languageand Literature. Foreign

Language Teaching and Research Press.
[3] George Perkins, The American Tradition in Literature, Volume I, Seven Edition. Mcgraw-hill Publishing Company. 